
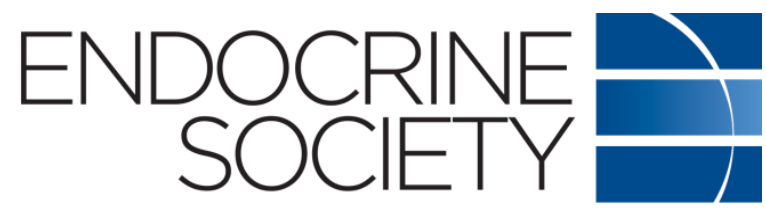

\title{
A comparative analysis of phenotypic predictors of mutations in familial hypercholesterolemia
}

\author{
Dick C Chan, Jing Pang, Amanda J Hooper, Damon A Bell, Timothy R Bates, John R \\ Burnett, Gerald F Watts
}

The Journal of Clinical Endocrinology \& Metabolism

Endocrine Society

Submitted: December 07, 2017

Accepted: January 29, 2018

First Online: February 02, 2018

\begin{abstract}
Advance Articles are PDF versions of manuscripts that have been peer reviewed and accepted but not yet copyedited. The manuscripts are published online as soon as possible after acceptance and before the copyedited, typeset articles are published. They are posted "as is" (i.e., as submitted by the authors at the modification stage), and do not reflect editorial changes. No corrections/changes to the PDF manuscripts are accepted. Accordingly, there likely will be differences between the Advance Article manuscripts and the final, typeset articles. The manuscripts remain listed on the Advance Article page until the final, typeset articles are posted. At that point, the manuscripts are removed from the Advance Article page.
\end{abstract}

DISCLAIMER: These manuscripts are provided "as is" without warranty of any kind, either express or particular purpose, or non-infringement. Changes will be made to these manuscripts before publication. Review and/or use or reliance on these materials is at the discretion and risk of the reader/user. In no event shall the Endocrine Society be liable for damages of any kind arising references to, products or publications do not imply endorsement of that product or publication. 
Phenotypic diagnostic testing for $\mathrm{FH}$

\title{
A comparative analysis of phenotypic predictors of mutations in familial hypercholesterolemia
}

\author{
Dick C Chan ${ }^{1}$, Jing Pang ${ }^{1}$, Amanda J Hooper ${ }^{1,2}$, Damon A Bell ${ }^{1,2,3}$, Timothy R Bates ${ }^{1,4}$, \\ John R Burnett ${ }^{1,2,3}$, Gerald F Watts ${ }^{1,3}$ \\ ${ }^{I}$ School of Medicine, University of Western Australia, Perth, Australia; ${ }^{2}$ Department of Clinical Biochemistry, \\ PathWest Laboratory Medicine WA, Royal Perth Hospital and Fiona Stanley Hospital Network, Perth, \\ Australia; ${ }^{3}$ Lipid Disorders Clinic, Department of Cardiology, Royal Perth Hospital, Perth, Australia; ${ }^{4}$ St John \\ of God Midland Public and Private Hospitals, Midland, Western Australia, Australia
}

Received 07 December 2017. Accepted 29 January 2018.

*These authors contributed equally to the manuscript

Context: The gold standard for diagnosing familial hypercholesterolemia $(\mathrm{FH})$ is identification of a causative pathogenic mutation. However, genetic testing is expensive and not widely available.

Objective To compare the validity of the Dutch Lipid Clinic Network (DLCN), Simon Broome (SB), Make Early Diagnosis to Prevent Early Deaths (MEDPED) and American Heart Association (AHA) criteria in predicting an FH-causing mutation.

Design, Setting, and Patients: An adult cohort of unrelated patients referred to a lipid clinic for genetic testing.

Main Outcome Measures: Odds ratio (OR), area-under-the-curve (AUC), sensitivity and specificity.

Results: A pathogenic FH-causing mutation was detected in $30 \%$ of 885 patients tested. Elevated LDL-cholesterol and personal or family history of tendon xanthomata were independent predictors of a mutation (ORs range 5.32-15.2, $P<0.001$ ). Prediction of a mutation for the DLCN and SB definite and MEDPED criteria (ORs 9.4, 11.7. 10.5, respectively) was higher than with the AHA criteria (OR 4.67). The balance of sensitivity and specificity was in decreasing order DLCN definite (Youden Index 0.487), MEDPED (0.457), SB definite (0.274) and AHA criteria (0.253), AUC being significantly higher with DLCN definite and MEDPED than other criteria $(P<0.05)$. Pre-treatment LDL-cholesterol and tendon xanthomata had the highest AUC in predicting a mutation.

Conclusions: The DLCN, SB and MEDPED criteria are valid predictors of an FH-causing mutation in patients referred to a lipid clinic, but concordance between these phenotypic criteria is only moderate. Use of pre-treatment LDL-cholesterol and tendon xanthomata alone may be particularly useful for deciding who should be genetically tested for FH.

We compared the validity of four diagnostic tools in predicting an $\mathrm{FH}$-causing mutation. The DLCN, SB definite and MEDPED phenotypes are valid predictors of a mutation in patients with suspected $\mathrm{FH}$.

\section{Introduction}

Familial hypercholesterolemia $(\mathrm{FH})$ is a co-dominantly inherited disorder resulting in elevated low density lipoprotein (LDL)-cholesterol concentration and increased risk of premature atherosclerotic cardiovascular disease (ASCVD) (1). FH is primarily caused by mutations in the LDL receptor $(L D L R)$, and less commonly by mutations in apolipoprotein $\mathrm{B}$ $(A P O B)$ and proprotein convertase subtilisin/kexin type 9 (PCSK9) genes (2). The prevalence of heterozygous $\mathrm{FH}$ is estimated to be 1 in 250 in unselected community populations (3-5). While genetic testing is the reference standard for diagnosing $\mathrm{FH}$ and has great value in risk assessment and cascade screening, it is expensive and not widely available (6). Deciding 
whether to undertake a genetic test in patients with phenotypic FH referred to a clinic is a key consideration.

The clinical diagnosis of FH is based on identifying a personal and family history of premature coronary artery disease (CAD), tendon xanthomata, corneal arcus and elevated LDL-cholesterol (7-9). However, there is no standardised phenotypic diagnosis of FH (10). The most commonly recommended diagnostic tools include the Dutch Lipid Clinic Network (DLCN), the Simon Broome (SB) and Make Early Diagnosis to Prevent Early Deaths (MEDPED) criteria (7-9). However, a detailed family history and physical stigmata required by the DLCN and SB criteria may be difficult to elicit. A simplified diagnosis of FH, based on LDL-cholesterol level and family history of elevated LDL-cholesterol or premature CAD, was recently proposed by the American Heart Association (AHA) (11).

We previously reported on the characteristics of patients with $\mathrm{FH}$ in a service for lipid disorders in Western Australia $(6,12)$. We now compare the diagnostic validity of the aforementioned clinical tools in discriminating between the presence and absence of a pathogenic gene variant causative of $\mathrm{FH}$. We thereby aimed to identify the optimal phenotype for predicting a mutation and how best to utilize genetic testing for $\mathrm{FH}$ in the clinic.

\section{Materials and Methods}

\section{Study design}

A cross-sectional comparison was undertaken of unrelated patients aged $\geq 18$ years with or without a recognised mutation causative of $\mathrm{FH}$. The care of these patients has been previously described $(6,12)$. In brief, adult patients with suspected FH were recruited via referral from general practice, coronary care or other specialists. Reasons for suspecting FH were generally an elevated plasma LDL-cholesterol with a family or personal history of CAD. Patients were evaluated by specialist physicians at the Lipid Disorders Clinic at Royal Perth Hospital (RPH, Perth, Western Australia); if the diagnosis was at least possible FH, they were genetically tested after appropriate counselling and consent. The study was approved by the RPH Human Research Ethics Committee.

\section{Clinical data}

Age, gender, history of coronary and other vascular disease, diabetes, hypertension, smoking status, examination findings (weight, height, blood pressure), and medications were recorded. The definition of CAD, diabetes, hypertension and obesity were previously described $(6,12)$.

\section{Phenotypic diagnosis of FH}

Details were obtained of family and personal history of hypercholesterolemia, premature coronary or vascular disease, tendon xanthomata (bilateral, subcutaneous nodules on Achilles tendons or at ligamentous insertions) and corneal arcus; pre-treatment plasma LDLcholesterol concentration was recorded. Where a pre-treatment plasma lipid profile was not available ( $25 \%$ of the cohort), a correction that accounted for type, dose and frequency of statins and use of ezetimibe (Supplementary Table 1), was used to estimate pre-treatment LDL-cholesterol concentrations (13). Patients were classified phenotypically, using the same individual variable, according to the DLCN, SB, MEDPED and AHA diagnostic criteria (Supplementary Table 2) (7-11). Since approximately 30\% of Lp(a) mass is cholesterol (14), in subsidiary analyses LDL-cholesterol was also adjusted for the cholesterol content of Lp(a) by subtracting $30 \%$ of total Lp(a) mass from the measured LDL-cholesterol concentration.

\section{Genetic diagnosis of FH}

The diagnosis of FH was based on the presence of a pathogenic gene variant. DNA extraction, multiplex ligation-dependent probe amplification (MLPA) and Sanger sequencing of the 18 exons of the $L D L R$, exon 7 of PCSK9, and part of $A P O B$ exons 26 and 29 was performed as previously described (6). In $10 \%$ of patients, genetic testing was based on next- 
generation sequencing (NGS), performed by Ion Torrent sequencing using a TargetSeq (Life Technologies) custom capture panel of lipid genes and polymorphisms, derived from LipidSeq (15). Mutation detection rates with NGS (29\%) and Sanger sequencing (30\%) were not significantly different. MLPA was performed in all patients with DLCN probable or definite FH in whom Sanger sequencing or NGS did not identify a mutation.

\section{Laboratory analyses}

Venous blood samples were collected during clinic visits. Plasma cholesterol, HDLcholesterol and triglyceride concentrations were determined by standard enzymatic methods. LDL-cholesterol was calculated by the Friedewald equation (16), but in patients with plasma triglyceride $>4.5 \mathrm{mmol} / \mathrm{L}$ a direct LDL-cholesterol assay was employed. Total apoB and Lp(a) (Quantia Lp(a) assay and standards) were determined by immunoassay (Abbott Laboratories, Abbott Park, IL), with inter-assay coefficient of variation of $<5 \%$.

\section{Statistical analyses}

All data were analysed using SPSS (version 21, Chicago, IL). Differences in clinical characteristics between $\mathrm{FH}$ index cases with and without a pathogenic mutation ( $L D L R$, $A P O B$ and $P C S K 9$ ) were tested with chi-squared or independent $t$-tests. Skewed variables, including plasma triglyceride and $\mathrm{Lp}$ (a) concentrations, were log-transformed. Logistic regression was used to assess prediction of a mutation. The discriminant value of plasma LDL-cholesterol concentration and the DLCN score in predicting a mutation were depicted using receiver operator characteristic (ROC) area-under-the-curve (AUC). Cohen's kappa coefficient was used to measure the phenotypic agreement between DLCN, SB, MEDPED and AHA criteria. The sensitivity, specificity, positive predictive valve (PPV), negative predictive value (NPV), and Youden index were employed to compare the diagnostic value of the clinical tools and their components in predicting a mutation. Improvement in prediction of a mutation with individual variable relative to the DLCN and SB definitions was estimated as differences between the AUCs and compared using C-statistics. Statistical significance was defined at the $5 \%$ level.

\section{RESULTS}

A total of 931 adult patients with at least "possible" FH according to the DLCN criterion ( score $\geq 3$ ) were genetically screened for a causative mutation for FH from March 2007 to September 2017. Patients with homozygous FH, compound or double heterozygous FH $(\mathrm{n}=6), L D L R$ or $A P O B$ variants of uncertain significance $(\mathrm{n}=30)$, pathogenic or uncertain $A B C G 5 / 8$ variants $(n=5)$, or those with frank secondary causes of hypercholesterolemia $(n=5)$ were excluded from the analysis. Of the remaining 885 index cases, 267 (30\%) of the screened cases had a pathogenic FH-causing mutation: 237 were found to have mutation in the LDLR gene (60\% missense, $20 \%$ nonsense/frameshift, $11 \%$ splice, $8 \%$ large deletion/duplication and $1 \%$ promoter variants), while others were heterozygous for $A P O B$ $(\mathrm{n}=25)$, PCSK9 $(\mathrm{n}=3)$ and APOE p.Leu167del $(\mathrm{n}=2)$ mutations.

The characteristics of the 885 patients with $(\mathrm{M}+)$ and without $(\mathrm{M}-)$ a mutation are shown in Table 1. M+ individuals were older, and had a higher frequency of non-Caucasian origin, tendon xanthomata and corneal arcus $(P<0.01$ for all $)$ and hypertension $(P<0.05)$ than $\mathrm{M}-$ patients. There were no significant differences in the proportion of men, smokers, or patients with CAD or cerebral/peripheral vascular disease, type 2 diabetes or obesity, and use of antihypertensive agents or aspirin between the M+ and M- groups. Compared with $\mathrm{M}$ individuals, M+ individuals had higher total cholesterol, non-HDL-cholesterol, LDLcholesterol (treated and pre-treatment) and apoB levels, and more frequent use of lipidlowering medication than M- individuals $(P<0.01$ for all). Plasma HDL-cholesterol and Lp(a) levels were not significantly different between the two groups $(P>0.05$ for both), but plasma 
triglyceride levels were significantly higher in the M- group. M+ individuals had a higher DLCN score (10.6 \pm 4.0 vs $6.2 \pm 2.5)$ and prevalence of DLCN definite FH (65\% vs $17 \%)$, SB definite $\mathrm{FH}(31 \%$ vs $4 \%$ ), MEDPED defined $\mathrm{FH}(79 \%$ vs $26 \%)$ and AHA defined FH (89\% vs $64 \%)$ than $M$ - individuals ( $P<0.001$ for all).

In univariate regression analysis (Table 2), family history of ASCVD (premature CAD and/or cerebral/peripheral vascular disease) or elevated LDL-cholesterol, presence of tendon xanthomata, corneal arcus and elevated LDL-cholesterol were all significant predictors of a mutation (odds ratios [ORs] range 3.00-27.0, $P<0.001$ for all). Using the DLCN criteria, the ORs for an FH-causing mutation were 9.47 (95\%CI 6.81-13.2) and 8.58 (5.40-13.6) for definite and for probable/definite $\mathrm{FH}$, respectively. The ORs for SB definite, possible/definite FH, MEDPED and AHA criteria were 11.7 (7.15-19.1), 7.79 (4.57-13.3), 10.5 (7.48-14.9) and 4.67 (3.07-7.09), respectively. Age and ethnicity were also significant predictors of a mutation (OR 0.977, 95\%CI 0.966-0.987 and 2.02, 95\%CI 1.32-3.09, respectively); i.e. mutations were more likely in younger and non-Caucasian patients. As seen in Table 2, family history, physical stigmata and elevated LDL-cholesterol remained independent predictors of the presence of a mutation in multivariate regression models. In stepwise regression analysis including tendon xanthomata, family history of physical stigmata and the DLCN definite criteria, elevated LDL-cholesterol $(\geq 8.5 \mathrm{mmol} / \mathrm{L})$ was the best predictor of the presence of a mutation ( $\beta$-coefficient 2.22, SE 0.351). The $\beta$-coefficients for tendon xanthomata, family history of physical stigmata and DLCN definite criteria were 0.924 (SE 0.319), 2.01 (0.278) and 1.01 (0.235), respectively. After adjusting for Lp(a)-cholesterol, elevated LDL-cholesterol remained an independent predictor of the presence of a mutation in the multivariate regression models. Inclusion of age, gender and ethnicity as independent variables also did not alter the significance of the aforementioned variables in detecting a mutation.

Table 3 shows the concordance and discordance rates between the four clinical diagnostic tools. There was a "moderate" agreement between DLCN and SB definite $(x=0.455)$, with an overall discordance rate of $19 \%$. However, there was a "poor" agreement between DLCN probable/definite and MEDPED criteria $(x=0.120$, concordance rate $67 \%$, discordance rate $33 \%)$, between SB possible/definite and MEDPED criteria $(x=0.185$, concordance rate $56 \%$, discordance rate $44 \%)$, and between the AHA criteria and DLCN definite $(x=0.120$, concordance rate $49 \%$, discordance rate $51 \%)$, SB definite $\mathrm{FH}(x=0.028$, concordance rate $36 \%$, discordance rate $64 \%)$ and MEDPED criteria $(x=0.176$, concordance rate $56 \%$, discordance rate 44\%). The kappa coefficient between the DLCN probable/definite and the SB possible/definite and AHA criteria was 0.378 and 0.338 , respectively, and between SB definite and MEDPED criteria 0.205, reflecting "fair" agreement between them. There was a "very good" agreement between the SB possible/definite and AHA criteria $(x=0.908$, concordance rate $99 \%$, discordance rate $1 \%$ ).

The ROC curve for LDL-cholesterol and DLCN score in predicting an FH-causing mutation was shown in Supplementary Figure 1. The higher the LDL-cholesterol levels and DLCN score, the greater the specificity and the lower the sensitivity in detecting a mutation. The ROC curve for LDL-cholesterol (AUC 0.835; 95\%CI 0.806-0.865) and for DLCN score (AUC 0.816; 95\%CI 0.784-0.847) were comparable in detecting a mutation (difference between ROC areas $0.020 ; 95 \%$ CI $-0.001-0.048 ; P=0.164)$. The AUC for LDL-cholesterol, after adjusting for Lp(a)-cholesterol, in detecting a mutation was 0.841 (95\%CI 0.812-0.870) which was also not significantly different from that for DLCN score as a continuous variable (difference between ROC areas 0.011; 95\%CI -0.017-0.040; $P=0.453$ ).

Table 4 shows the sensitivity, specificity, PPV, NPV, Youden index and AUC for different diagnostic criteria in detecting an FH-causing mutation. A family history of physical stigmata, the presence of tendon xanthomata and an LDL-cholesterol $\geq 8.5 \mathrm{mmol} / \mathrm{L}$ had high 
specificities ( $>95 \%$ for all), but relatively low sensitivities (range 31.1-36.7\%) in detecting a mutation. A family history of premature CAD or hypercholesterolemia had high sensitivity (90.2\%), but low specificity $(24.4 \%)$ in detecting a mutation. Lower plasma LDL-cholesterol concentrations were more sensitive (from $36.7 \%$ to $98.9 \%$ ) but less specific (from $97.9 \%$ to $14.7 \%$ ) in detecting a mutation. The highest Youden index among the individual diagnostic components was 0.485 with an LDL-cholesterol $\geq 6.5 \mathrm{mmol} / \mathrm{L}$.

With the composite diagnostic criteria, Table 4 also shows that SB definite FH had a higher specificity $(96.3 \%)$ but lower sensitivity $(31.1 \%)$ in detecting a mutation than DLCN definite FH (specificity $83.5 \%$, sensitivity 65.2\%) and MEDPED criteria (specificity 88.9\%, sensitivity 56.8\%). However, the DLCN definite FH (Youden index 0.487) and MEDPED criteria (Youden index 0.457 ) had a better balance between sensitivity and specificity than the SB definite (Youden index 0.274) in detecting a mutation. While the AHA criteria had a high sensitivity (89.1\%), its specificity (36.2\%) was lower compared with DLCN definite, SB Definite or MEDPED criteria. The Youden indices for the composite were in decreasing order: DLCN definite, MEDPED criteria, DLCN probable/definite, SB definite, SB possible/definite and AHA criteria.

With reference to a DLCN definite diagnosis, the AUCs were significantly less $(P<0.05$ for all) with family history of ASCVD (or elevated LDL-cholesterol), family and personal history of physical stigmata, personal history of ASCVD, elevated LDL-cholesterol ( $\geq 5.0 \mathrm{mmol} / \mathrm{L}$ or $\geq 8.5 \mathrm{mmol} / \mathrm{L}$ ), DLCN probable/definite $\mathrm{FH}, \mathrm{SB}$ possible/definite $\mathrm{FH}$ and AHA criteria (AUCs range -0.067 to -0.239 ). With reference to a SB definite diagnosis, the AUCs were significantly less $(P<0.05$ for all) with family history of ASCVD (or elevated LDL-cholesterol), personal history of ASCVD, corneal arcus and elevated LDL-cholesterol $\geq 5.0 \mathrm{mmol} / \mathrm{L}$ (AUCs range -0.069 to -0.133 ). The AUC for an LDL-cholesterol $\geq 6.5 \mathrm{mmol} / \mathrm{L}$ was significantly higher than a SB definite diagnosis $(0.106,95 \%$ CI $0.067-0.144)$ but not different from a DLCN definite diagnosis $(-0.001,95 \% \mathrm{CI}-0.037-0.035)$. With reference to a DLCN probable/definite or SB possible/definite diagnosis, the AUCs were significantly less with family history of ASCVD (or elevated LDL-cholesterol), personal history of ASCVD and corneal arcus and LDL-cholesterol $\geq 5.0 \mathrm{mmol} / \mathrm{L}$ (AUCs range -0.062 to -0.173 ). The AUC for the MEDPED criteria was similar to the DLCN definite FH (0.487 vs 0.457 , $\mathrm{P}>0.05)$, but significantly higher compared with the SB definite, DLCN probable/definite or $\mathrm{SB}$ possible/definite diagnosis $(\mathrm{P}<0.05$ for all). While family history of physical stigmata showed no significant difference in AUCs, an LDL-cholesterol $\geq 6.5 \mathrm{mmol} / \mathrm{L}$ had a significant higher AUCs when compared with the DLCN probable/definite or SB possible/definite diagnosis (0.066 and 0.107, respectively, $P<0.001)$.

\section{Discussion}

In a large sample of patients referred to a specialist clinic, we demonstrated that the DLCN, SB and MEDPED phenotypes were valid predictors of an FH-causing mutation, the AHA criteria having the lowest diagnostic specificity. Among individual phenotypic components, the pre-treatment LDL-cholesterol and presence of tendon xanthomata afforded the best discriminant value in predicting a mutation that overall matched the DLCN definite, SB definite and MEDPED criteria. The concordance between these phenotypic tools for FH was, however, only moderate.

Several studies have examined the relationship between clinical diagnostic tools and genetically defined FH. Damgaard et al reported that the DLCN and SB criteria were comparably effective in identifying most carriers of an $\mathrm{FH}$-causing mutation, with specificities $>85 \%$, but sensitivities of $<45 \%$ (17); the discriminant value of individual diagnostic components was not investigated. The diagnostic yield of the DLCN and SB criteria in predicting the common FH-causing mutations was later confirmed in a larger 
community population, but there was limited information on family history and no records of physical stigmata of FH (4). Haralambos et al reported on the value of a modified DLCN criteria in predicting FH-causing mutations in Wales, but the findings were limited by lack of genetic data in individuals with lower DLCN score (13). Silva et al found that the DLCN score was a significant predictor of a mutation, but SB diagnostic criteria were not examined (18). Civeira et al also reported that the MEDPED criteria had high sensitivity and specificity in predicting a mutation in Spanish patients, but tendon xanthomata and age-adjusted LDLcholesterol were the most significant predictors of a mutation (19). We extend previous reports by comparing the discriminant value of different phenotypic criteria in predicting an FH-causing mutation among referrals to a specialist clinic.

That a higher proportion of $\mathrm{M}+$ than $\mathrm{M}$ - patients in our study fulfilled a phenotypic diagnosis of FH according to the DLCN definite, SB definite, MEDPED and AHA criteria was anticipated. Tendon xanthomata and markedly elevated LDL-cholesterol are classical hallmarks of FH (7-9, 11). Consistent with previous studies $(18,19,21)$, the presence of tendon xanthomata and/or corneal arcus in the potential index cases and family members were independent predictors of the presence of an FH-causing mutation (Table 2). Likewise, a pre-treatment LDL-cholesterol above $4.9 \mathrm{mmol} / \mathrm{L}$ was confirmed as an independent predictor of a mutation. Given that tendon xanthomata and elevated LDL-cholesterol are major criteria for the DLCN and SB diagnostic tools $(7,9)$, it was anticipated that these phenotypic components were highly predictive of a mutation. While the AHA tool was also predictive of a mutation, its specificity and PPV were significantly less than DLCN and SB definite and MEDPED criteria. In agreement with Civeira et al (19), we found that a history of premature $\mathrm{CAD}$ was not a significant predictor of a mutation. This accords with recent understanding that the major causes of premature CAD are due to multigenic and adverse lifestyle factors. As suggested elsewhere, familial combined hyperlipidemia and common hypercholesterolemia with elevated Lp(a) are frequent phenocopies of FH (22).

Although we studied referrals to a specialist clinic, approximately $30 \%$ of patients with a definite phenotypic FH by DLCN and SB criteria did not have an FH-causing mutation. This points to polygenic hypercholesterolemia (attributed to common, small-effect LDLcholesterol raising alleles), or unrecognized genetic causes of autosomal dominant hypercholesterolemia $(23,24)$. Conversely, more than $15 \%$ of patients with a mutation were not identified by a DLCN or SB definite diagnosis. This suggests less severe FH phenotypes associated with pathogenic $L D L R$ variants causing less LDL-receptor dysfunction, reduced genetic penetrance and/or to co-inheritance of protective genes (25). Earlier detection and treatment with statins can also modify phenotypic FH (26). The phenotypic diagnosis of FH appears more dependent on the pre-treatment LDL-cholesterol than on other clinical features of FH, consistent with the earlier MEDPED recommendations (8), although clinical stigmata allow greater refinement of the diagnosis $(8,27)$.

The strength of the study was the use of well standardised, comprehensive criteria for characterising patients. However, there were limitations. The sample was predominantly Caucasian, but reflected the ethnic distribution of the Australian population. That the likelihood of an FH-causing mutation was increased in non-Caucasians reflects higher specificity in this group of applying Caucasian criteria. The diagnosis of FH in children based on LDL-cholesterol were not examined, but are reviewed elsewhere (28). Because of ascertainment bias, our results may have limited applicability to the community diagnosis of $\mathrm{FH}$, but our conclusions may be valuable when applied to targeted screening of electronic health records for FH in primary care (29). Approximately $25 \%$ of our patients were on cholesterol-lowering medication and pre-treatment LDL-cholesterol was derived using adjustments that might not have fully reflected true values (13). Testing for cholesterol allelic 
gene scores might have helped identify patients with isolated polygenic hypercholesterolemia (24).

\section{Implications}

The reference diagnosis of $\mathrm{FH}$ is the identification of a pathogenic mutation that affects the clearance of LDL via the LDL-receptor pathway $(1,2)$. Genetic testing may be used to predict ASCVD risk (19), but is currently expensive and not widely available. Moreover, not all patients consent to genetic testing owing to personal preferences and potential discrimination by employers and insurers $(3,5,11,25)$. Knowledge of the phenotypic predictors of a mutation may be useful for improving the accuracy of diagnosis where genetic testing is not available, or not consented to, and for rationing genetic testing where resources are limited.

With rising awareness of FH in primary care, an increasing number of patients will be referred to specialist clinics for confirmation of the diagnosis. Because of limited resources, it may be necessary to phenotypically identify patients who are very likely to have FH in whom genetic confirmation may be less valuable (unless combined with cascade screening), patients with an intermediate clinical likelihood in whom genetic testing may be particularly useful, and patients with low likelihood in whom genetic testing could be wasteful. Cascade screening for FH using LDL-cholesterol and genetic testing is potentially cost-effective (27, $30,31)$. Phenotypic cascade testing from index cases with a definite clinical diagnosis is also intuitively more cost-effective than from index cases with lesser probabilities of FH. Hence, genetic testing of index cases with an intermediate probability of $\mathrm{FH}$ may offer an effective use of laboratory resources in the context of cascade testing.

Based on our results, Figure 1 shows the application of the four phenotypic diagnostic tools to the detection of a mutation and to enabling decision regarding genetic testing in patients referred to clinics. In this scheme, genetic testing could be recommended in patients with an intermediate probability of having a mutation and could be considered in patients with a low phenotypic probability in whom the clinical suspicion of $\mathrm{FH}$ is high. A caveat is that although prediction of a mutation appears statistically comparable among DLCN, SB and MEDPED criteria, the phenotypic classification of patients can be discordant (Table 3).

Given that information on individual family members are not always available, a simpler scheme shown in Figure 2 utilizes the pre-treatment LDL-cholesterol and presence of tendon xanthomata in potential index cases to predict the likelihood of a mutation and value of genetic testing. Use of pre-treatment LDL-cholesterol as the primary criterion accords with earlier MEDPED recommendations (8) and is useful for identifying patients with intermediate likelihood of $\mathrm{FH}$ in whom genetic confirmation is required. Inclusion of tendon xanthomata as a second criterion further improves the specificity of the diagnosis of $\mathrm{FH}$.

In adult patients referred to a specialist lipid clinic, prediction of an FH-causing mutation, or the decision to request a genetic test, could simply be based on the pre-treatment LDLcholesterol and presence of a personal (or family) history of tendon xanthomata. While florid tendon xanthomata are currently less frequent among heterozygous FH (32), their earlier detection may be enhanced with ultrasonography (33). This may provide a more standardised approach to the diagnosis of FH and overcome the notable discordance between DLCN and SB clinical diagnostic criteria. Country-specific LDL-cholesterol levels should replace the original MEDPED criteria $(8,27)$. Services with requisite laboratory and clinical resources may elect to genetically test all patients referred with a putative diagnosis of FH, but the costeffectiveness of this policy remains to be evaluated.

\section{Acknowledgements}

We thank Professor Frank van Bockxmeer (Royal Perth Hospital, School of Biomedical Sciences, University of Western Australia) for providing expert clinical advice. 
Address for correspondence and reprint: Winthrop Professor Gerald F Watts, School of Medicine, University of Western Australia, Royal Perth Hospital, GPO Box X2213, Perth, WA 6847, Australia. Tel: +61-8-9224-0245; Fax: +61-8-9224-0246, Email: gerald.watts@uwa.edu.au

Disclosure summary:

The authors report no conflicts of interest in this work

\section{References}

1. Austin MA, Hutter CM, Zimmern RL, Humphries SE. Familial hypercholesterolemia and coronary heart disease: A huge association review. Am J Epidemiol 2004;160:421-429.

2. Soutar AK, Naoumova RP. Mechanisms of disease: genetic causes of familial hypercholesterolemia. Nat Clin Pract Cardiovasc Med 2007;4:214-225.

3. Watts GF, Shaw JE, Pang J, Magliano DJ, Jennings GL, Carrington MJ. Prevalence and treatment of familial hypercholesterolemia in Australian communities. Int J Cardiol 2015;185:69-71.

4. Benn M, Watts GF, Tybjaerg-Hansen A, Nordestgaard BG. Mutations causative of familial hypercholesterolemia: screening of 98098 individuals from the Copenhagen General Population Study estimated a prevalence of 1 in 217. Eur Heart J;2016:37:1384-1394.

5. Nordestgaard BG, Chapman MJ, Humphries SE, Ginsberg HN, Masana L, Descamps OS, Wiklund O, Hegele RA, Raal FJ, Defesche JC, Wiegman A, Santos RD, Watts GF, Parhofer KG, Hovingh GK, Kovanen PT, Boileau C, Averna M, Borén J, Bruckert E, Catapano AL, Kuivenhoven JA, Pajukanta P, Ray K, Stalenhoef AF, Stroes E, Taskinen MR, Tybjærg-Hansen A; European Atherosclerosis Society Consensus Panel. European Atherosclerosis Society Consensus Panel. Familial hypercholesterolemia is underdiagnosed and undertreated in the general population: guidance for clinicians to prevent coronary heart disease. Eur Heart J 2013;34:3478-3490.

6. Hooper AJ, Nguyen LT, Burnett JR, Bates TR, Bell DA, Redgrave TG, Watts GF, van Bockxmeer FM. Genetic analysis of familial hypercholesterolemia in Western Australia. Atherosclerosis 2012;224:430-434.

7. Steering S, Register B. Mortality in treated heterozygous familial hypercholesterolemia: implications for clinical management. Scientific steering committee on behalf of the Simon Broome register group. Atherosclerosis 1999;142:105-112.

8. Williams RR, Hunt SC, Schumacher MC, Hegele RA, Leppert MF, Ludwig EH, Hopkins PN. Diagnosing heterozygous familial hypercholesterolemia using new practical criteria validated by molecular genetics. Am J Cardiol;1993:171-176.

9. World Health Organization . Familial hypercholesterolemia (FH). Report of a second WHO consultation. Geneva, Switz: World Health Organization; 1999. Available from: http://apps.who.int/iris/bitstream/10665/66346/1/WHO_HGN_FH_CONS_99.2.pdf. 10. Ahmad ZS, Andersen RL, Andersen LH, O'Brien EC, Kindt I, Shrader P, Vasandani C, Newman CB, deGoma EM, Baum SJ, Hemphill LC, Hudgins LC, Ahmed CD, Kullo IJ, Gidding SS, Duffy D, Neal W, Wilemon K, Roe MT, Rader DJ, Ballantyne CM, Linton MF, Duell PB, Shapiro MD, Moriarty PM, Knowles JW. US physician practices for diagnosing familial hypercholesterolemia: data from the CASCADE-FH registry. J Clin Lipidol 2016;10:1223-1229

11. Gidding SS, Champagne MA, de Ferranti SD, Defesche J, Ito MK, Knowles JW, McCrindle B, Raal F, Rader D, Santos RD, Lopes-Virella M, Watts GF, Wierzbicki AS; American Heart Association Atherosclerosis, Hypertension, and Obesity in Young Committee of Council on Cardiovascular Disease in Young, Council on Cardiovascular and Stroke Nursing, Council on Functional Genomics and Translational Biology, and Council on 
Lifestyle and Cardiometabolic Health. The agenda for familial hypercholesterolemia: a scientific statement from the American Heart Association. Circulation 2015;132:2167-2192. 12. Chan DC, Pang J, Hooper AJ, Burnett JR, Bell DA, Bates TR, van Bockxmeer FM, Watts GF. Elevated lipoprotein(a), hypertension and renal insufficiency as predictors of coronary artery disease in patients with genetically confirmed heterozygous familial hypercholesterolemia. Int J Cardiol. 2015 Dec 15;201:633-8.

13. Haralambos K, Whatley SD, Edwards R, Gingell R, Townsend D, Ashfield-Watt P, Lansberg P, Datta DBN, McDowell IFW. Clinical experience of scoring criteria for familial hypercholesterolemia (FH) genetic testing in Wales. Atherosclerosis 2015;240:190-196.

14. Kinpara K, Okada H, Yoneyama A, Okubo M, Murase T. Lipoprotein(a)-cholesterol: A significant component of serum cholesterol. Clin Chim Acta. 2011;412:1783-1787.

15. Johansen CT, Dubé JB, Loyzer MN, MacDonald A, Carter DE, McIntyre AD, Cao H, Wang J, Robinson JF, Hegele RA. LipidSeq: a next-generation clinical resequencing panel for monogenic dyslipidemias. J Lipid Res 2014;55:765-772.

16. Friedewald WT, Levy RI, Fredrickson DS. Estimation of the concentration of lowdensity lipoprotein cholesterol in plasma, without use of the preparative ultracentrifuge. Clin Chem 1972;18:499-502.

17. Damgaard D, Larsen ML, Nissen PH, Jensen JM, Jensen HK, Soerensen VR, Jensen LG, Faergeman O. The relationship of molecular genetic to clinical diagnosis of familial hypercholesterolemia in a Danish population. Atherosclerosis 2005;180:155-160.

18. Silva PRS, Jannes CE, Oliveira TGM, Miname MH, Rocha VZ, Chacra AP, Gurgel MHC, Montenegro RM, Rodrigues Sobrinho CRM, Bello Moreira AS, Assad MHV, Pinto MRC, Tada MT, Santos RD, Pereira AC, Krieger JE. Evaluation of clinical and laboratory parameters used in the identification of index cases for genetic screening of familial hypercholesterolemia in Brazil. Atherosclerosis 2017;263:257-262.

19. Civeira F, Ros E, Jarauta E, Plana N, Zambon D, Puzo J, Martinez de Esteban JP, Ferrando J, Zabala S, Almagro F, Gimeno JA, Masana L, Pocovi M. Comparison of genetic versus clinical diagnosis in familial hypercholesterolemia. Am J Cardiol 2008;102:11871193.

20. Khera AV, Won HH, Peloso GM, Lawson KS, Bartz TM, Deng X, van Leeuwen EM, Natarajan P, Emdin CA, Bick AG, Morrison AC, Brody JA, Gupta N, Nomura A, Kessler T, Duga S, Bis JC, van Duijn CM, Cupples LA, Psaty B, Rader DJ, Danesh J, Schunkert H, McPherson R, Farrall M, Watkins H, Lander E, Wilson JG, Correa A, Boerwinkle E, Merlini PA, Ardissino D, Saleheen D, Gabriel S, Kathiresan S. Diagnostic yield of sequencing familial hypercholesterolemia genes in patients with severe hypercholesterolemia. J Am Coll Cardiol 2016;67:2578-2589.

21. Clarke RE, Padayachee ST, Preston R, McMahon Z, Gordon M, Graham C, Crook MA, Wierzbicki AS. Effectiveness of alternative strategies to define index case phenotypes to aid genetic diagnosis of familial hypercholesterolemia. Heart 2013;99:175-180.

22. Ellis KL, Pang J, Chan DC, Hooper AJ, Bell DA, Burnett JR, Watts GF. Familial combined hyperlipidemia and hyperlipoprotein(a) as phenotypic mimics of familial hypercholesterolemia: Frequencies, associations and predictions. J Clin Lipidol 2016:10:1329-1337.

23. Fouchier S, Dallinga-Thie G, Meijers JC, Zelcer N, Kastelein JJ, Defesche JC, Hovingh GK. Mutations in STAP1 are associated with autosomal dominant hypercholesterolemia. Circ Res 2014;115:552-555.

24. Talmud PJ, Shah S, Whittall R, Futema M, Howard P, Cooper JA, Harrison SC, Li K, Drenos F, Karpe F, Neil HA, Descamps OS, Langenberg C, Lench N, Kivimaki M, Whittaker J, Hingorani AD, Kumari M, Humphries SE. Use of low-density lipoprotein cholesterol gene 
score to distinguish patients with polygenic and monogenic familial hypercholesterolemia: a case-control study. Lancet 2013;381:1293-1301.

25. Iacocca MA, Hegele RA. Recent advances in genetic testing for familial hypercholesterolemia. Expert Rev Mol Diagn. 2017;17:641-651.

26. Alonso R, Mata P, Zambón D, Mata N, Fuentes-Jiménez F. Early diagnosis and treatment of familial hypercholesterolemia: improving patient outcome. Expert Rev Cardiovasc Ther. 2013;11:327-342.

27. Watts GF, Gidding S, Wierzbicki AS, Toth PP, Alonso R, Brown WV, Bruckert E, Defesche J, Lin KK, Livingston M, Mata P, Parhofer KG, Raal FJ, Santos RD, Sijbrands EJ, Simpson WG, Sullivan DR, Susekov AV, Tomlinson B, Wiegman A, Yamashita S, Kastelein JJ. Integrated guidance on the care of familial hypercholesterolemia from the International FH Foundation. Int J Cardiol 2014;171:309-325.

28. Wiegman A, Gidding SS, Watts GF, Chapman MJ, Ginsberg HN, Cuchel M, Ose L, Averna M, Boileau C, Borén J, Bruckert E, Catapano AL, Defesche JC, Descamps OS, Hegele RA, Hovingh GK, Humphries SE, Kovanen PT, Kuivenhoven JA, Masana L, Nordestgaard BG, Pajukanta P, Parhofer KG, Raal FJ, Ray KK, Santos RD, Stalenhoef AF, Steinhagen-Thiessen E, Stroes ES, Taskinen MR, Tybjærg-Hansen A, Wiklund O; European Atherosclerosis Society Consensus Panel. Familial hypercholesterolemia in children and adolescents: gaining decades of life by optimizing detection and treatment. Eur Heart J; 2015:36:2425-2437.

29. Troeung L, Arnold-Reed D, Chan She Ping-Delfos W, Watts GF, Pang J, Lugonja M, Bulsara M, Mortley D, James M, Brett T. A new electronic screening tool for identifying risk of familial hypercholesterolaemia in general practice. Heart 2016: 102:855-861.

30. Lázaro P, Pérez de Isla L, Watts GF, Alonso R, Norman R, Muñiz O, Fuentes F, Mata N, López-Miranda J, González-Juanatey JR, Díaz-Díaz JL, Blasco AJ, Mata P. Costeffectiveness of a cascade screening program for the early detection of familial hypercholesterolemia. J Clin Lipidol 2017;11:260-271.

31. Knowles JW, Rader DJ, Khoury MJ. Cascade screening for familial hypercholesterolemia and the use of genetic testing. JAMA 2017; 318:381-382.

32. Kindt I; Mata P, Knowles JW. The role of registries and genetic databases in familial hypercholesterolemia. Curr Opin Lipidol 2007; 28:152-160.

33. Junyent M, Gilabert R, Zambón D, Núñez I, Vela M, Civeira F, Pocoví M, Ros E. The use of Achilles tendon sonography to distinguish familial hypercholesterolemia from other genetic dyslipidemias. Arterioscler Thromb Vasc Biol 2005; 25:2203-2208.

Figure 1 Flowcharts showing the use of the phenotypic (A) Dutch Lipid Clinic Network, (B) Simon Broom, (C) Make Early Diagnosis to Prevent Early Deaths and (D) American Heart Association diagnostic tools in predicting the likelihood of a $\mathrm{FH}$-causing mutation and assisting decisions on whether to undertake genetic testing. Genetic testing is arbitrarily not routinely recommended where probability of a mutation is $\langle 15 \%$, is recommended when the probability of a mutation is $15-60 \%$ and is optional when the probability of a mutation $>60 \%$.

Figure 2 Flowchart showing use of LDL-cholesterol concentration and presence of tendon xanthomata in predicting the likelihood of a FH-causing mutation and assisting decisions on whether to undertake genetic testing. Genetic testing is arbitrarily not routinely recommended where probability of a mutation is $<15 \%$, is recommended when the probability of a mutation is $15-60 \%$ and is optional when the probability of a mutation $>60 \%$.

Table 1. Demographic, clinical and biochemical characteristics of the patients with FH in relation to presence (Mutation +) and absence (Mutation -) of an FH-causing mutation 
Table 1. Demographic, clinical and biochemical characteristics of the patients with FH in relation to presence (Mutation +) and absence (Mutation -) of an FH-causing mutation

\begin{tabular}{|c|c|c|c|c|}
\hline & Total & Mutation + & Mutation & $P$ \\
\hline Number of subjects & 885 & 267 & 618 & \\
\hline Age at diagnosis (years) & $51 \pm 13$ & $48 \pm 14$ & $52 \pm 13$ & $<0.001$ \\
\hline Male (\%) & 46 & 41 & 47 & 0.091 \\
\hline Ethnicity Caucasian (\%) & 89 & 84 & 91 & 0.004 \\
\hline Asian (\%) & 6 & 10 & 5 & \\
\hline Other (Mixed/Aboriginal/African/Middle Eastern) (\%) & 5 & 6 & 4 & \\
\hline Early CAD (\%) & 44 & 48 & 43 & 0.141 \\
\hline Early cerebral or peripheral vascular disease (\%) & 4 & 5 & 4 & 0.719 \\
\hline Tendon xanthomata (\%) & 12 & 31 & 4 & $<0.001$ \\
\hline Corneal arcus (\%) & 27 & 36 & 24 & 0.001 \\
\hline Smoking (ever) (\%) & 42 & 41 & 42 & 0.767 \\
\hline Hypertension (\%) & 29 & 23 & 32 & 0.012 \\
\hline Type 2 Diabetes $(\%)$ & 7 & 5 & 7 & 0.375 \\
\hline Obesity $\left(\mathrm{BMI}>30 \mathrm{~kg} / \mathrm{m}^{2}\right)(\%)$ & 30 & 28 & 32 & 0.386 \\
\hline On lipid-lowering medication (\%) & 66 & 75 & 63 & 0.001 \\
\hline On anti-hypertensive medication (\%) & 29 & 27 & 30 & 0.422 \\
\hline On aspirin (\%) & 28 & 31 & 27 & 0.223 \\
\hline Total cholesterol $(\mathrm{mmol} / \mathrm{L})$ & $5.7 \pm 1.8$ & $6.0 \pm 2.0$ & $5.6 \pm 1.7$ & 0.018 \\
\hline Triglyceride $(\mathrm{mmol} / \mathrm{L})$ & $1.8 \pm 1.1$ & $1.4 \pm 0.7$ & $1.9 \pm 1.2$ & $<0.001$ \\
\hline HDL-cholesterol $(\mathrm{mmol} / \mathrm{L})$ & $1.4 \pm 0.6$ & $1.3 \pm 0.4$ & $1.4 \pm 0.6$ & 0.168 \\
\hline Non-HDL-cholesterol (mmol/L) & $4.4 \pm 1.8$ & $4.6 \pm 2.0$ & $4.3 \pm 1.6$ & 0.007 \\
\hline LDL-cholesterol $(\mathrm{mmol} / \mathrm{L})$ & $3.6 \pm 1.6$ & $3.9 \pm 1.9$ & $3.4 \pm 1.5$ & $<0.001$ \\
\hline Pre-treated LDL-cholesterol (mmol/L) & $6.6 \pm 1.7$ & $8.1 \pm 1.8$ & $6.0 \pm 1.1$ & $<0.001$ \\
\hline Lipoprotein(a) (g/L) & $0.30(0.28-0.32)$ & $0.27(0.24-0.31$ & $0.31(0.29-0.35)$ & 0.073 \\
\hline ApoB $(g / L)$ & $1.1 \pm 0.4$ & $1.2 \pm 0.4$ & $1.1 \pm 0.3$ & 0.001 \\
\hline Dutch Lipid Clinic Network (DLCN) criteria score** & $7.6 \pm 3.6$ & $10.6 \pm 4.0$ & $6.2 \pm 2.5$ & $<0.001$ \\
\hline DLCN category*** & 31 & 65 & 17 & $<0.001$ \\
\hline Probable FH (\%) & 36 & 27 & 40 & $<0.001$ \\
\hline Possible FH (\%) & 33 & 8 & 43 & $<0.001$ \\
\hline Simon Broome*** & 12 & 31 & 4 & $<0.001$ \\
\hline Possible FH (\%) & 63 & 63 & 63 & 0.685 \\
\hline Probable Heterozygous FH (\%) & 42 & 79 & 26 & $<0.001$ \\
\hline American Heart Association $\quad$ Heterozygous FH (\%) & 71 & 89 & 64 & $<0.001$ \\
\hline
\end{tabular}

Values are expressed as mean \pm SD or geometric mean $(95 \% \mathrm{CI}) ; P$-value for Mutation + vs Mutation -;

**DLCN score refers to the score without the genetic analysis component [ie. family history, clinical history, physical examination (tendon xanthomata and corneal arcus) and LDL-cholesterol level only]; tendon xanthomata were diagnosed with reference to the Achilles tendons; ***DLCN and Simon Broome FH categories do not take account of the genetic analysis component into the classification.

Table 2. Predictors of the presence of an FH causing mutation according to individual phenotypic criteria and composite diagnostic tools for $\mathrm{FH}$

Table 2. Predictors of the presence of an FH causing mutation according to individual phenotypic criteria and composite diagnostic tools for $\mathrm{FH}$

\begin{tabular}{|c|c|c|c|c|c|c|}
\hline 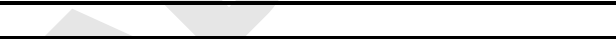 & \multicolumn{3}{|c|}{ Univariate logistic regression } & \multicolumn{3}{|c|}{ Multivariate logistic regression } \\
\hline 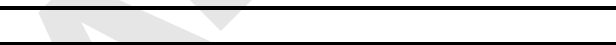 & $\mathrm{OR}$ & $95 \% \mathrm{CI}$ & $P$ & $\mathrm{OR}_{\dagger}^{\dagger}$ & $95 \% \mathrm{CI}$ & $P$ \\
\hline \multicolumn{7}{|l|}{ Individual phenotypic criteria } \\
\hline \multicolumn{7}{|l|}{ Family history } \\
\hline $\begin{array}{l}\text { Premature CAD and/or vascular disease or elevated } \\
\text { LDL-cholesterol }\end{array}$ & 3.00 & $1.92-4.67$ & $<0.001$ & 3.24 & $1.86-5.64$ & $<0.001$ \\
\hline Tendinous xanthomata and/or corneal arcus & 12.0 & $7.39-19.4$ & $<0.001$ & 8.65 & $\begin{array}{l}4.98- \\
15.03\end{array}$ & $<0.001$ \\
\hline \multicolumn{7}{|l|}{ Clinical history } \\
\hline Presence of premature CAD & 1.24 & $0.93-1.66$ & 0.139 & & & \\
\hline Presence of premature cerebral or PVD & 0.82 & $0.39-1.71$ & 0.597 & & & \\
\hline \multicolumn{7}{|l|}{ Physical examination } \\
\hline Tendinous xanthomata & 10.7 & $6.64-17.2$ & $<0.001$ & 5.32 & $2.94-9.61$ & $<0.001$ \\
\hline Corneal arcus & 1.75 & $1.29-2.40$ & $<0.001$ & 1.55 & $1.04-2.31$ & 0.033 \\
\hline \multicolumn{7}{|l|}{ Pre-treated LDL-cholesterol (mmol/L) } \\
\hline LDL-cholesterol * & 2.81 & $2.41-3.27$ & $<0.001$ & & & \\
\hline LDL-cholesterol $\geq 8.5$ & 27.0 & $14.8-49.3$ & $<0.001$ & 16.1 & $8.42-30.6$ & $<0.001$ \\
\hline
\end{tabular}




\begin{tabular}{|l|c|c|c|c|c|c|}
\hline LDL-cholesterol $\geq 6.5$ & 8.77 & $6.20-12.4$ & $<0.001$ & 7.54 & $5.11-11.2$ & $<0.001 \ddagger$ \\
\hline LDL-cholesterol $\geq 5.0$ & 15.2 & $4.77-48.5$ & $<0.001$ & 14.9 & $4.48-49.3$ & $<0.001 \ddagger$ \\
\hline Composite diagnostic tools & & & & & & \\
\hline DLCN score * & 1.49 & $1.41-1.58$ & $<0.001$ & & & \\
\hline DLCN Definite FH** & 9.47 & $6.81-13.2$ & $<0.001$ & & & \\
\hline DLCN Probable/Definite FH** & 8.58 & $5.40-13.6$ & $<0.001$ & & & \\
\hline Simon Broome Definite FH** & 11.7 & $7.15-19.1$ & $<0.001$ & & & \\
\hline Simon Broome Possible/Definite FH & 7.79 & $4.57-13.3$ & $<0.001$ & & & \\
\hline MEDPED Probable Heterozygous FH & 10.5 & $7.48-14.9$ & $<0.001$ & & & \\
\hline American Heart Association Heterozygous FH & 4.67 & $3.07-7.09$ & $<0.001$ & & & \\
\hline
\end{tabular}

*Expressed as a continuous variable; **refers to the classification without the genetic analysis component.

${ }^{\dagger}$ Multivariate logistic regression (variables enter on model: family history of premature CAD and/or vascular disease or elevated LDL-cholesterol, family history of tendon xanthomata and/or corneal arcus, tendon xanthomata, corneal arcus, and pre-treated LDL-cholesterol $\geq 8.5 \mathrm{mmol} / \mathrm{L}$.); $\ddagger$ Replacing LDL-cholesterol $\geq 8.5 \mathrm{mmol} / \mathrm{L}$ with lower LDL-cholesterol cut-off.

Table 3. Concordance and discordance rates for diagnostic outcomes according to Dutch Lipid Criteria Network (DLCN), Simon Broome (SB), Make Early Diagnosis to Prevent Early Deaths (MEDPED) and American Heart Association (AHA) phenotypic tools

Table 3. Concordance and discordance rates for diagnostic outcomes according to Dutch Lipid Criteria Network (DLCN), Simon Broome (SB), Make Early Diagnosis to Prevent Early Deaths (MEDPED) and American Heart Association (AHA) phenotypic tools.

\begin{tabular}{|c|c|c|c|}
\hline & Concordance rate & Discordance rate & Kappa coefficient* \\
\hline \multicolumn{4}{|l|}{ DLCN definite FH vs SB definite FH } \\
\hline For total group $(n=885)$ & $81 \%$ & $19 \%$ & 0.455 \\
\hline For positives $(\mathrm{n}=276)^{* *}$ & $38 \%$ & $62 \%$ & \\
\hline For negatives $(\mathrm{n}=609)^{* *}$ & $98 \%$ & $2 \%$ & \\
\hline \multicolumn{4}{|l|}{ DLCN probable/definite $\mathrm{FH}$ vs SB possible/definite F| } \\
\hline For total group $(\mathrm{n}=885)$ & $74 \%$ & $26 \%$ & 0.378 \\
\hline For positives $(\mathrm{n}=594) * *$ & $87 \%$ & $13 \%$ & \\
\hline For negatives $(\mathrm{n}=291)^{* *}$ & $49 \%$ & $51 \%$ & \\
\hline \multicolumn{4}{|l|}{ DLCN definite FH vs MEDPED FH } \\
\hline For total group $(n=885)$ & $73 \%$ & $27 \%$ & 0.3717 \\
\hline For positives $(\mathrm{n}=276) * *$ & $73 \%$ & $27 \%$ & \\
\hline For negatives $(\mathrm{n}=609)^{* *}$ & $72 \%$ & $28 \%$ & \\
\hline \multicolumn{4}{|l|}{ DLCN probable/definite FH vs MEDPED FH } \\
\hline For total group $(\mathrm{n}=885)$ & $67 \%$ & $33 \%$ & 0.120 \\
\hline For positives $(\mathrm{n}=276)^{* *}$ & $56 \%$ & $44 \%$ & \\
\hline For negatives $(\mathrm{n}=609)^{* *}$ & $88 \%$ & $12 \%$ & \\
\hline \multicolumn{4}{|l|}{ DLCN definite FH vs AHA FH } \\
\hline For total group $(n=885)$ & $49 \%$ & $51 \%$ & 0.120 \\
\hline For positives $(\mathrm{n}=276)^{* *}$ & $83 \%$ & $17 \%$ & \\
\hline For negatives $(\mathrm{n}=609)^{* *}$ & $34 \%$ & $66 \%$ & \\
\hline \multicolumn{4}{|l|}{ DLCN probable/definite FH vs AHA FH } \\
\hline For total group $(n=885)$ & $71 \%$ & $29 \%$ & 0.338 \\
\hline For positives $(\mathrm{n}=594) * *$ & $82 \%$ & $18 \%$ & \\
\hline For negatives $(\mathrm{n}=291)^{* *}$ & $49 \%$ & $51 \%$ & \\
\hline \multicolumn{4}{|l|}{ SB definite FH vs MEDPED FH } \\
\hline For total group $(n=885)$ & $65 \%$ & $35 \%$ & 0.205 \\
\hline For positives $(\mathrm{n}=106)^{* *}$ & $79 \%$ & $21 \%$ & \\
\hline For negatives $(\mathrm{n}=779)^{* *}$ & $63 \%$ & $37 \%$ & \\
\hline \multicolumn{4}{|l|}{ SB definite FH vs AHA FH } \\
\hline For total group $(n=885)$ & $36 \%$ & $64 \%$ & 0.028 \\
\hline For positives $(\mathrm{n}=106)^{* *}$ & $79 \%$ & $21 \%$ & \\
\hline For negatives $(\mathrm{n}=779)^{* *}$ & $30 \%$ & $70 \%$ & \\
\hline \multicolumn{4}{|l|}{ SB possible/definite FH vs MEDPED FH } \\
\hline For total group $(\mathrm{n}=885)$ & $56 \%$ & $44 \%$ & 0.185 \\
\hline For positives $(\mathrm{n}=664)^{* *}$ & $48 \%$ & $52 \%$ & \\
\hline For negatives $(\mathrm{n}=221)^{* *}$ & $78 \%$ & $22 \%$ & \\
\hline \multicolumn{4}{|l|}{ SB possible/definite FH vs AHA FH } \\
\hline For total group $(n=885)$ & $99 \%$ & $1 \%$ & 0.908 \\
\hline For positives $(\mathrm{n}=664)^{* *}$ & $95 \%$ & $5 \%$ & \\
\hline For negatives $(\mathrm{n}=221)^{* *}$ & $100 \%$ & $0 \%$ & \\
\hline
\end{tabular}




\begin{tabular}{|c|c|c|c|}
\hline MEDPED FH vs AHA FH & & & \\
\hline For total group ( $\mathrm{n}=885)$ & $56 \%$ & $44 \%$ & 0.176 \\
\hline For positives $(\mathrm{n}=370)^{* *}$ & $48 \%$ & $52 \%$ & \\
\hline For negatives $(\mathrm{n}=515)^{* *}$ & $75 \%$ & $25 \%$ & \\
\hline
\end{tabular}

*Poor agreement $<0.20$, fair agreement 0.20 to 0.40 , moderate agreement 0.40 to 0.60 , good agreement 0.60 to 0.80 and very good agreement 0.80 to 1.00

**Positives and negatives refer to outcomes by the former phenotypic diagnostic category.

Table 4. Sensitivity, specificity, positive (PPV) and negative predictive value (NPV), Youden index and area under curve (AUC) of diagnostic test for $\mathrm{FH}$

Table 4. Sensitivity, specificity, positive (PPV) and negative predictive value (NPV), Youden index and area under curve (AUC) of diagnostic test for FH.

\begin{tabular}{|c|c|c|c|c|c|c|c|c|c|c|}
\hline Criteria & $\begin{array}{l}\text { Sensitivity } \\
\% \text { (95\% } \\
\text { CI) }\end{array}$ & $\begin{array}{l}\text { Specificity } \\
\%(95 \% \\
\text { CI] })\end{array}$ & $\begin{array}{c}\text { PPV } \\
\%, \\
(95 \% \\
\text { CI })\end{array}$ & $\begin{array}{c}\text { NPV } \\
\%, \\
{[95 \%} \\
\text { CI] })\end{array}$ & $\begin{array}{c}\text { Youden } \\
\text { index }\end{array}$ & $\begin{array}{l}\text { AUC, } \\
(95 \% \\
\text { CI })\end{array}$ & $\begin{array}{c}\text { Change in } \\
\text { AUC, } \\
\text { Relative to, } \\
\text { DLCN } \\
\text { definite } \\
\text { FH**, } \\
(95 \% \text { CI })\end{array}$ & $\begin{array}{c}\text { Change in } \\
\text { AUC, } \\
\text { Relative to, } \\
\text { SB definite } \\
\text { FH**, } \\
(95 \% \text { CI })\end{array}$ & $\begin{array}{c}\text { Change in } \\
\text { AUC, } \\
\text { Relative to } \\
\text { DLCN } \\
\text { definite/ } \\
\text { probable } \\
\text { FH**, } \\
(95 \% \text { CI })\end{array}$ & $\begin{array}{c}\text { Change in } \\
\text { AUC, Relative } \\
\text { to, SB } \\
\text { definite/possible } \\
\text { FH } * *,(95 \% \\
\text { CI), }\end{array}$ \\
\hline \multicolumn{11}{|l|}{$\begin{array}{l}\frac{\text { Individual }}{\text { diagnostic }} \\
\text { criteria }\end{array}$} \\
\hline $\begin{array}{l}\text { Family history of } \\
\text { premature } \\
\text { ASCVD or } \\
\text { elevated LDL- } \\
\text { cholesterol, }\end{array}$ & $\begin{array}{c}90.2(85.9, \\
93.4)\end{array}$ & $\begin{array}{c}24.4(21.1, \\
28.1)\end{array}$ & $\begin{array}{l}34.0 \\
(30.5 \\
37.7)\end{array}$ & $\begin{array}{l}85.3 \\
(79.0 \\
90.0)\end{array}$ & 0.146 & $\begin{array}{c}0.573 \\
(0.534, \\
0.613)\end{array}$ & $\begin{array}{c}-0.170^{*}(- \\
0.211,- \\
0.128)\end{array}$ & $\begin{array}{l}-0.063 *(- \\
0.103,- \\
0.024)\end{array}$ & $\begin{array}{c}-0.103^{*}(- \\
0.136,- \\
0.070)\end{array}$ & $\begin{array}{c}-0.062 *(- \\
0.082,-0.043)\end{array}$ \\
\hline $\begin{array}{l}\text { Family History } \\
\text { of tendon } \\
\text { xanthomata } \\
\text { and/or corneal } \\
\text { arcus }\end{array}$ & $\begin{array}{l}32.5, \\
(27.1, \\
38.6)\end{array}$ & $\begin{array}{l}96.1, \\
(94.2, \\
97.4)\end{array}$ & $\begin{array}{l}78.4 \\
(69.4 \\
85.4)\end{array}$ & $\begin{array}{l}76.7 \\
(73.5, \\
79.6)\end{array}$ & 0.286 & $\begin{array}{l}0.644, \\
(0.601, \\
0.686)\end{array}$ & $\begin{array}{c}-0.100 *,(- \\
0.138,- \\
0.061)\end{array}$ & $\begin{array}{c}0.007,(- \\
0.030 \\
0.044)\end{array}$ & $\begin{array}{c}-0.033,(- \\
0.071 \\
0.005)\end{array}$ & $\begin{array}{c}0.008,(-0.029 \\
0.044)\end{array}$ \\
\hline $\begin{array}{l}\text { Presence of } \\
\text { premature CAD }\end{array}$ & $\begin{array}{l}47.9, \\
(41.8, \\
54.1)\end{array}$ & $\begin{array}{l}57.4, \\
(53.4, \\
61.4)\end{array}$ & $\begin{array}{l}32.7 \\
(28.2 \\
37.7)\end{array}$ & $\begin{array}{l}71.9, \\
(67.6, \\
75.7)\end{array}$ & 0.053 & $\begin{array}{l}0.527, \\
(0.485, \\
0.568)\end{array}$ & $\begin{array}{c}-0.216^{*},(- \\
0.260,- \\
0.172)\end{array}$ & $\begin{array}{c}-0.110^{*},(- \\
0.156,- \\
0.064)\end{array}$ & $\begin{array}{c}-0.150^{*},(- \\
0.188,- \\
0.111)\end{array}$ & $\begin{array}{c}-0.109 *,(- \\
0.153,-0.065)\end{array}$ \\
\hline $\begin{array}{l}\text { Presence of } \\
\text { premature } \\
\text { cerebral or PVD }\end{array}$ & $\begin{array}{l}3.74, \\
(1.91, \\
6.99)\end{array}$ & $\begin{array}{l}95.7, \\
(94.1, \\
96.9)\end{array}$ & $\begin{array}{l}26.3, \\
(14.0, \\
43.4)\end{array}$ & $\begin{array}{l}69.7, \\
(66.4, \\
72.7)\end{array}$ & 0.001 & $\begin{array}{l}0.496 \\
(0.455 \\
0.537) \\
\end{array}$ & $\begin{array}{c}-0.239 *,(- \\
0.275,- \\
0.204) \\
\end{array}$ & $\begin{array}{c}-0.133^{*},(- \\
0.166,- \\
0.100)\end{array}$ & $\begin{array}{c}-0.173^{*},(- \\
0.202,- \\
0.143)\end{array}$ & $\begin{array}{c}-0.132^{*},(- \\
0.160,-0.104)\end{array}$ \\
\hline $\begin{array}{l}\text { Tendon } \\
\text { xanthomata }\end{array}$ & $\begin{array}{l}31.1, \\
(25.7, \\
37.1)\end{array}$ & $\begin{array}{l}96.0, \\
(94.0- \\
97.3) \\
\end{array}$ & $\begin{array}{l}76.9, \\
(67.6, \\
84.2)\end{array}$ & $\begin{array}{l}76.3, \\
(73.1, \\
79.2)\end{array}$ & 0.271 & $\begin{array}{l}0.635, \\
(0.592, \\
0.678)\end{array}$ & $\begin{array}{c}-0.108^{*},(- \\
0.140,- \\
0.077) \\
\end{array}$ & $\begin{array}{c}-0.002,(- \\
0.004 \\
0.001)\end{array}$ & $\begin{array}{c}-0.041^{*},(- \\
0.077,- \\
0.006)\end{array}$ & $\begin{array}{c}-0.001,(- \\
0.036,0.034)\end{array}$ \\
\hline Corneal arcus & $\begin{array}{l}35.6, \\
(29.9, \\
41.7) \\
\end{array}$ & $\begin{array}{l}76.1, \\
(72.4, \\
79.3) \\
\end{array}$ & $\begin{array}{l}39.1, \\
(33.0, \\
45.4) \\
\end{array}$ & \begin{tabular}{|l|}
73.2, \\
$(69.6$, \\
$76.6)$ \\
\end{tabular} & 0.117 & $\begin{array}{l}0.558, \\
(0.516, \\
0.600) \\
\end{array}$ & $\begin{array}{c}-0.185^{*},(- \\
0.219,- \\
0.151) \\
\end{array}$ & $\begin{array}{c}-0.079 *,(- \\
0.119,- \\
0.038) \\
\end{array}$ & $\begin{array}{c}-0.118^{*},(- \\
0.154,- \\
0.083) \\
\end{array}$ & $\begin{array}{c}-0.078^{*},(- \\
0.120,-0.036)\end{array}$ \\
\hline $\begin{array}{l}\text { LDL-cholesterol } \\
\geq 8.5 \mathrm{mmol} / \mathrm{L}\end{array}$ & $\begin{array}{l}36.7, \\
(31.0, \\
42.8) \\
\end{array}$ & $\begin{array}{l}97.9, \\
(96.3, \\
98.8) \\
\end{array}$ & $\begin{array}{l}88.3, \\
(80.5, \\
93.4) \\
\end{array}$ & $\begin{array}{c}78.1, \\
(75.0, \\
81.0) \\
\end{array}$ & 0.346 & $\begin{array}{l}0.673, \\
(0.631, \\
0.715) \\
\end{array}$ & $\begin{array}{c}-0.070^{*},(- \\
0.101,- \\
0.039) \\
\end{array}$ & $\begin{array}{c}0.036^{*}, \\
(0.001,- \\
0.071)\end{array}$ & $\begin{array}{c}-0.003,(- \\
0.039 \\
0.032) \\
\end{array}$ & $\begin{array}{c}0.037^{*},(0.001 \\
0.073)\end{array}$ \\
\hline $\begin{array}{l}\text { LDL-cholesterol } \\
\geq 6.5 \mathrm{mmol} / \mathrm{L}\end{array}$ & $\begin{array}{l}80.5, \\
(75.2, \\
85.0)\end{array}$ & $\begin{array}{l}68.0, \\
(64.1, \\
71.6)\end{array}$ & $\begin{array}{l}52.1, \\
(47.1, \\
57.0)\end{array}$ & $\begin{array}{l}89.0 \\
(85.7, \\
91.6)\end{array}$ & 0.485 & $\begin{array}{l}0.742, \\
(0.707, \\
0.778)\end{array}$ & $\begin{array}{c}-0.001,(- \\
0.037 \\
0.035)\end{array}$ & $\begin{array}{l}0.106^{*}, \\
(0.067, \\
0.144)\end{array}$ & $\begin{array}{l}0.066^{*}, \\
(0.037, \\
0.095)\end{array}$ & $\begin{array}{c}0.107^{*},(0.071 \\
0.143)\end{array}$ \\
\hline $\begin{array}{l}\text { LDL-cholesterol } \\
\geq 5.0 \mathrm{mmol} / \mathrm{L}\end{array}$ & $\begin{array}{l}98.9, \\
(96.5, \\
99.7) \\
\end{array}$ & $\begin{array}{l}14.7, \\
(12.1, \\
17.8) \\
\end{array}$ & $\begin{array}{l}33.4, \\
(30.1, \\
36.8) \\
\end{array}$ & $\begin{array}{l}96.8, \\
(90.3, \\
99.2) \\
\end{array}$ & 0.136 & $\begin{array}{l}0.568, \\
(0.529, \\
0.607) \\
\end{array}$ & $\begin{array}{c}-0.175^{*},(- \\
0.209,- \\
0.141) \\
\end{array}$ & $\begin{array}{c}-0.069 *,(- \\
0.101,- \\
0.037) \\
\end{array}$ & $\begin{array}{c}-0.108^{*},(- \\
0.136,- \\
0.081) \\
\end{array}$ & $\begin{array}{c}-0.068^{*},(- \\
0.089,-0.046)\end{array}$ \\
\hline \multicolumn{11}{|l|}{$\begin{array}{l}\text { Composite } \\
\text { diagnostic tools }\end{array}$} \\
\hline $\begin{array}{l}\text { DLCN Definite } \\
\text { FH, }\end{array}$ & $\begin{array}{c}65.2(59.1, \\
70.8)\end{array}$ & $\begin{array}{c}83.5(80.3 \\
86.3)\end{array}$ & $\begin{array}{l}63.0 \\
(57.0, \\
68.7) \\
\end{array}$ & \begin{tabular}{|l}
84.7 \\
$(81.6$ \\
$87.4)$ \\
\end{tabular} & 0.487 & $\begin{array}{r}0.743 \\
(0.705, \\
0.781) \\
\end{array}$ & Reference, & $\begin{array}{l}0.106^{*} \\
(0.075, \\
0.138),\end{array}$ & $\begin{array}{l}0.067 * \\
(0.034, \\
0.100),\end{array}$ & $\begin{array}{c}0.107^{*}(0.070 \\
0.145)\end{array}$ \\
\hline $\begin{array}{l}\text { DLCN } \\
\text { Probable/Definite } \\
\text { FH } \\
\end{array}$ & $\begin{array}{l}91.8, \\
(87.6, \\
94.6) \\
\end{array}$ & $\begin{array}{l}43.5, \\
(39.6, \\
47.5) \\
\end{array}$ & $\begin{array}{l}41.2, \\
(37.2, \\
45.3) \\
\end{array}$ & $\begin{array}{l}92.4, \\
(88.6, \\
95.1) \\
\end{array}$ & 0.353 & $\begin{array}{l}0.676, \\
(0.641, \\
0.712) \\
\end{array}$ & $\begin{array}{c}-0.067^{*},(- \\
0.100,- \\
0.034) \\
\end{array}$ & $\begin{array}{l}0.040^{*}, \\
(0.004, \\
0.075) \\
\end{array}$ & Reference & $\begin{array}{c}0.041^{*},(0.011 \\
0.070)\end{array}$ \\
\hline $\begin{array}{l}\text { Simon Broome } \\
\text { Definite FH }\end{array}$ & $\begin{array}{l}31.1, \\
(25.7, \\
37.1) \\
\end{array}$ & $\begin{array}{l}96.3, \\
(94.4, \\
97.6) \\
\end{array}$ & $\begin{array}{l}78.3, \\
(69.0, \\
85.5) \\
\end{array}$ & \begin{tabular}{|l}
76.4, \\
$(73.2$, \\
$79.3)$ \\
\end{tabular} & 0.274 & $\begin{array}{l}0.637, \\
(0.594, \\
0.680) \\
\end{array}$ & $\begin{array}{c}-0.106^{*},(- \\
0.138,- \\
0.075) \\
\end{array}$ & Reference & $\begin{array}{c}-0.040^{*},(- \\
0.075,- \\
0.004) \\
\end{array}$ & $\begin{array}{c}0.001,(-0.034 \\
0.036)\end{array}$ \\
\hline $\begin{array}{l}\text { Simon Broome } \\
\text { Possible/Definite } \\
\text { FH }\end{array}$ & $\begin{array}{l}94.0 \\
(90.3 \\
96.4)\end{array}$ & $\begin{array}{l}33.2 \\
(29.5, \\
37.1)\end{array}$ & $\begin{array}{l}37.8, \\
(34.1, \\
41.6)\end{array}$ & $\begin{array}{l}92.8, \\
(88.3 \\
95.7)\end{array}$ & 0.272 & $\begin{array}{l}0.636, \\
(0.599, \\
0.673)\end{array}$ & $\begin{array}{c}-0.107^{*},(- \\
0.145,- \\
0.070)\end{array}$ & $\begin{array}{c}-0.001,(- \\
0.036 \\
0.034)\end{array}$ & $\begin{array}{c}-0.041^{*},(- \\
0.070,- \\
0.011)\end{array}$ & Reference \\
\hline
\end{tabular}




\begin{tabular}{|l|c|c|c|c|c|c|c|c|c|c|}
\hline MEDPED & 56.8, & 88.9, & 78.7, & 74.1, & & 0.764, & $0.021,(-$ & $0.088^{*}$ & $0.127^{*}$, & $0.128^{*},(0.098$, \\
Probable FH & $(51.5$, & $(85.8$, & $(73.1$, & $(70.4$, & 0.457 & $(0.729$, & 0.009, & $(0.058$, & $(0.097,-$ & $0.158)$ \\
& $61.8)$ & $91.4)$ & $83.3)$ & $77.5)$ & & $0.799)$ & $0.051)$ & $0.118)$ & $0.157)$ & $0.18)^{2}$ \\
\hline American Heart & 89.1, & 36.2, & 37.7, & 88.5, & & 0.627, & $-0.116^{*},(-$ & $-0.010,(-$ & $-0.050^{*},(-$ & $-0.009,(-$ \\
Association FH & $(84.6$, & $(32.5$, & $(33.9$, & $(83.8$, & 0.253 & $(0.589$, & $0.158,-$ & 0.051, & $0.082,-$ & $0.024,0.006)$ \\
& $92.5)$ & $40.2)$ & $41.6)$ & $92.1)$ & & $0.665)$ & $0.075)$ & $0.031)$ & $0.017)$ & \\
\hline
\end{tabular}

\footnotetext{
**A positive change (delta) in AUC value indicates an increased discriminant value in detecting an FH mutation compared with the reference test

**A negative change (delta) in AUC value indicates a decreased discriminant value in detecting an FH mutation compared with the reference test

*indicates significant differences in delta AUC compared with the reference using C-statistics; $P<0.05$.
} 


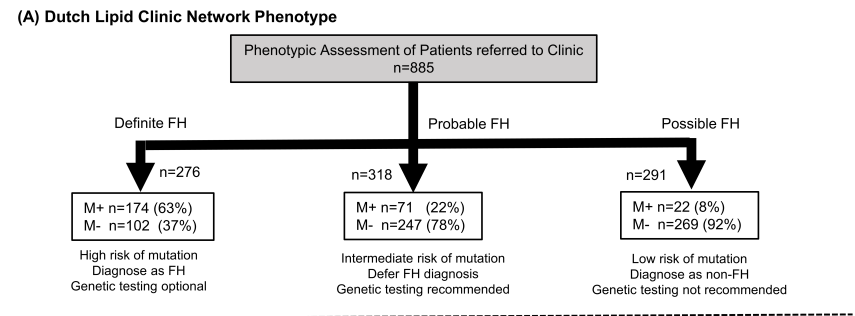

(B) Simon Broome Phenotype

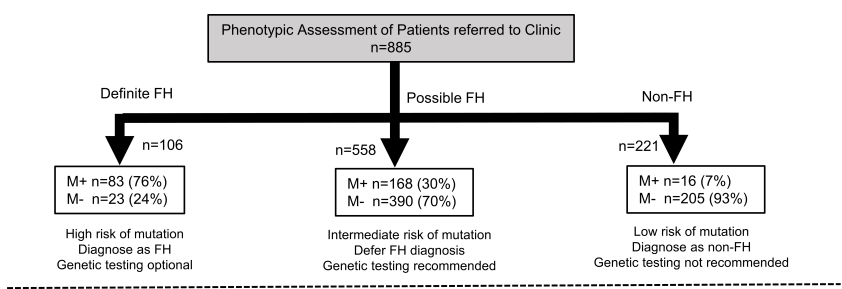

(C) Make Early Diagnosis to Prevent Early Deaths Phenotype

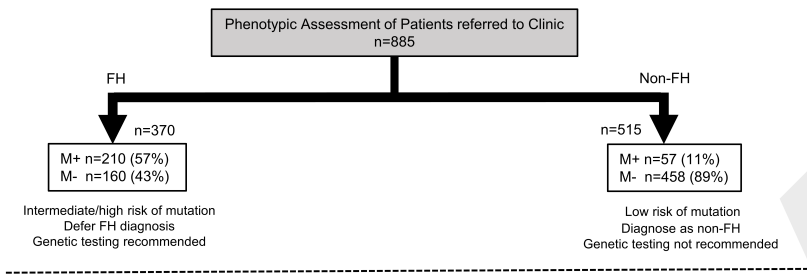

(D) American Heart Association Phenotype

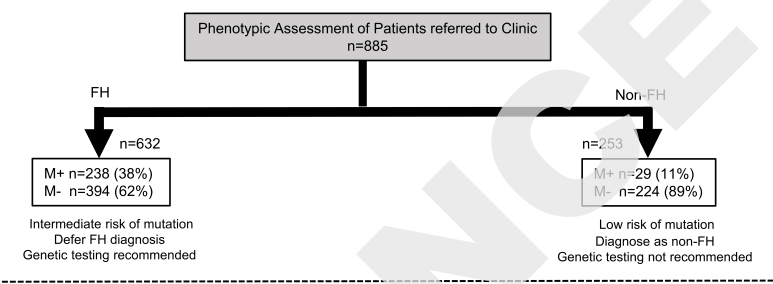




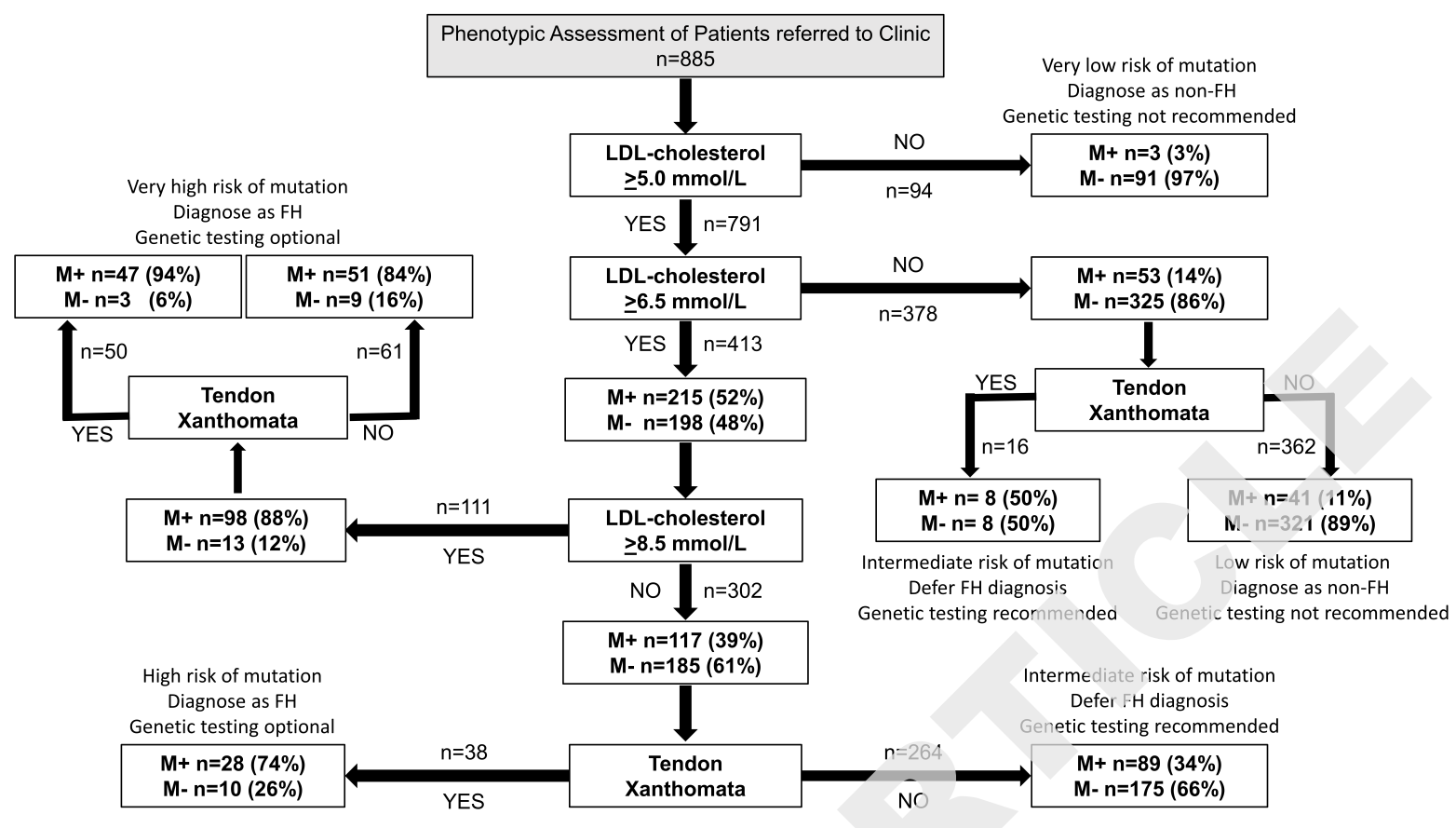

